\title{
Population dynamics of honey bee nucleus colonies exposed to industrial pollutants *
}

\author{
JJ Bromenshenk 1**, JL Gudatis 1, SR Carlson 1, \\ JM Thomas 2, MA Simmons 2 \\ 1 Division of Biological Sciences, University of Montana, Missoula, Montana 59812; \\ ${ }^{2}$ Terrestrial Sciences Section, Pacific Northwest Laboratory Richland, Washington 99352, USA
}

(Received 6 March 1990; accepted 25 February 1991)

\begin{abstract}
Summary - Nucleus colonies (nucs) of $\approx 4500$ honey bees (Apis mellifera $L$ ) were evaluated as an alternative to full-size colonies for monitoring pollution impacts. Fifty nucs were deployed at 5 sites along a transect on Vashon Island, Washington. This provided a gradient of exposure to arsenic and cadmium from industrial sources. After $40 \mathrm{~d}$, statistically significant differences were observed among sites for mean mass and numbers of bees $(P \leq 0.01)$, honey yield $(P \leq 0.07)$, and arsenic and cadmium content of forager bees $(P \leq 0.001)$. These findings are discussed in terms of exposure to heavy metals and observed changes in colony dynamics, especially brood rearing and hoarding of pollen, nectar, and honey.
\end{abstract}

Apis mellifera / population dynamics / biological indicator / pollutant

\section{INTRODUCTION}

Honey bees (Apis mellifera $\mathrm{L}$ ) are used to monitor the distribution and impact of various hazardous chemicals, including trace elements, heavy metals, radionuclides, pesticides; and organic contaminants such as polychlorinated biphenyls (Fritzsch and Bremer, 1975; Bromenshenk, 1979, 1988; Wallwork-Barber et al, 1982; Celli, 1983; Höffel and Müller, 1983; Bromen- shenk et al, 1985; Anderson and Wojtas, 1986; Morse et al, 1987).

The millions of bee colonies in the United States offer an extensive, in-place monitoring network. However, beekeepers are understandably reluctant to place bees in areas where they are exposed to hazardous chemicals. However, nucs, a low-cost alternative to full-size colonies, can fill such voids or provide an inexpensive sampling grid.

\footnotetext{
* The research described in this article was funded by the Environmental Protection Agency under assistance agreements CR-810929-01, CR-811387-01-1 and CR-810292-01-0 to the University of Montana and a related services agreement TD 1589 with the Department of Energy under contract DE-ACO6-76RLO 1830. It has not been subjected to Agency review, and therefore does not necessarily reflect the views of the Agency; no official endorsement should be inferred.

"* Correspondence and reprints
} 
This research was conducted on Vashon Island near a heavily industrialized region of Tacoma, Washington (fig 1a). Previously, we mapped exposures to arsenic and cadmium based on concentrations of these metals in forager bees (Bromenshenk et al, 1985; Bromenshenk and Preston, 1986). For this study, we assessed the feasibility of using small populations of honey bees to identify and quantify responses associated with in situ exposures to environmental contaminants.

\section{MATERIALS AND METHODS}

Each 4-frame nucleus hive was one-fourth the size of a standard hive body $(19.5 \mathrm{~cm} \times 26.5 \mathrm{~cm}$ $x 28 \mathrm{~cm}$ ) and initially contained a newly mated queen and $400 \pm 17$ ( \pm 2 SD) $\mathrm{g}$ of bees, or $\approx$ 4500 individuals. The nucs were stocked with bees from full-size hives at a Vashon Island apiary exposed to relatively low concentrations of cadmium and arsenic, as determined by chemical residue analysis of forager bees (Bromenshenk et al, 1985).

Bees shaken from the stock hives were randomly allocated to the nucs based on a table of random numbers (Sokal and Rohlf, 1981). Each nuc was supplied with $3375 \mathrm{~cm}^{2}$ frames containing beeswax foundation and $1375 \mathrm{~cm}^{2}$ frame containing a fully drawn comb. The drawn comb provided space for immediate storage of pollen and nectar and for egg laying. Each unit was immediately fed $1500 \mathrm{ml}$ of sucrose.

Fifty nucs were deployed on Vashon Island on July $10,1984,3 \mathrm{~d}$ after their establishment. The nucs were placed at 5 sites (fig 1a) along the known pollution gradient, extending northeast and downwind from a heavily industrialized region of Commencement Bay near Tacoma, Washington.

Twelve nucs, set on stands in groups of 3 , were placed at the south (\#1, high exposure), mid-island (\#3, medium exposure), and north (\#5, low exposure) sites. Six nucs, in groups of 3 , were placed at the intermediate sites (\#2 and \#4).

Total hive mass was calculated each week. Initial and final mass were recorded for hive components (hives and frames) and for live adult bees, which were shaken from the frames for weighing. A platform balance (range 0$59 \mathrm{~kg}, \pm 6 \mathrm{~g}$ ), calibrated with weights traceable to the National Bureau of Standards, determined the mass.

Weekly estimates of adult bee populations were obtained from counts of frames covered by bees. Fractions of frames covered were visually estimated. Bees were restricted to the hives the prior evening. Counts were conducted in the cool temperatures at dawn while the bees were clustered. At the study's end, both frame coverage and mass of bees were determined.

Acetate tracings of each side of each frame were made weekly to obtain estimates of total

Fig 1.a. Map of the study area in Puget Sound, WA. The number ( $n$ ) of nucs equalled 12 at Sites 1,2 and 3 , and 6 at Sites 4 and 5 . Wind blew from the Commencement Bay towards Vashon Island at an average speed of $3.5 \mathrm{knots}$ and a $17.8 \%$ frequency for the first 2 wk and $53 \%$ for the last 4 wk of the experiment (data provided by the Puget Sound Air Pollution Control Agency). The sites ranked $1>3$ $>2>4 \geq 5$ from high to low in exposure to arsenic, and $1>3>4>2 \geq 5$ in cadmium. All measurements were made at weekly intervals. $b$. Non-linear regression of bee mass versus bee numbers as indicated by frames covered by clustered bees. c. Best-fit models for population growth curves. $d$. Mass of bees versus arsenic content of forager bees. Data points are values for sets of 3 nucs, pooled at the time of sampling (wk 5). e. Area of drawn wax per mini-hive at each site. An overall mean $C V=24.6$ was observed. $f$. Area of uncapped brood (eggs and larvae) per mini-hive at each site. An overall mean CV $=40.9 \%$ was observed. g. Weekly measurements of areas of capped brood (pupae) in mini-hives at each site. An overall mean CV $=47.3 \%$ was observed. h. Weekly measurements of area of total brood (capped and uncapped) per mini-hive at each site. An overall mean $\mathrm{CV}=$ $38.7 \pm 9.0 \%$ was observed. 
a
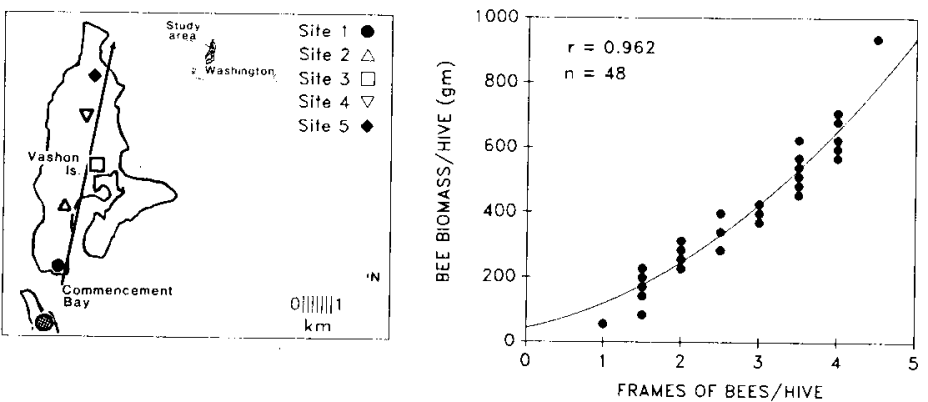

b
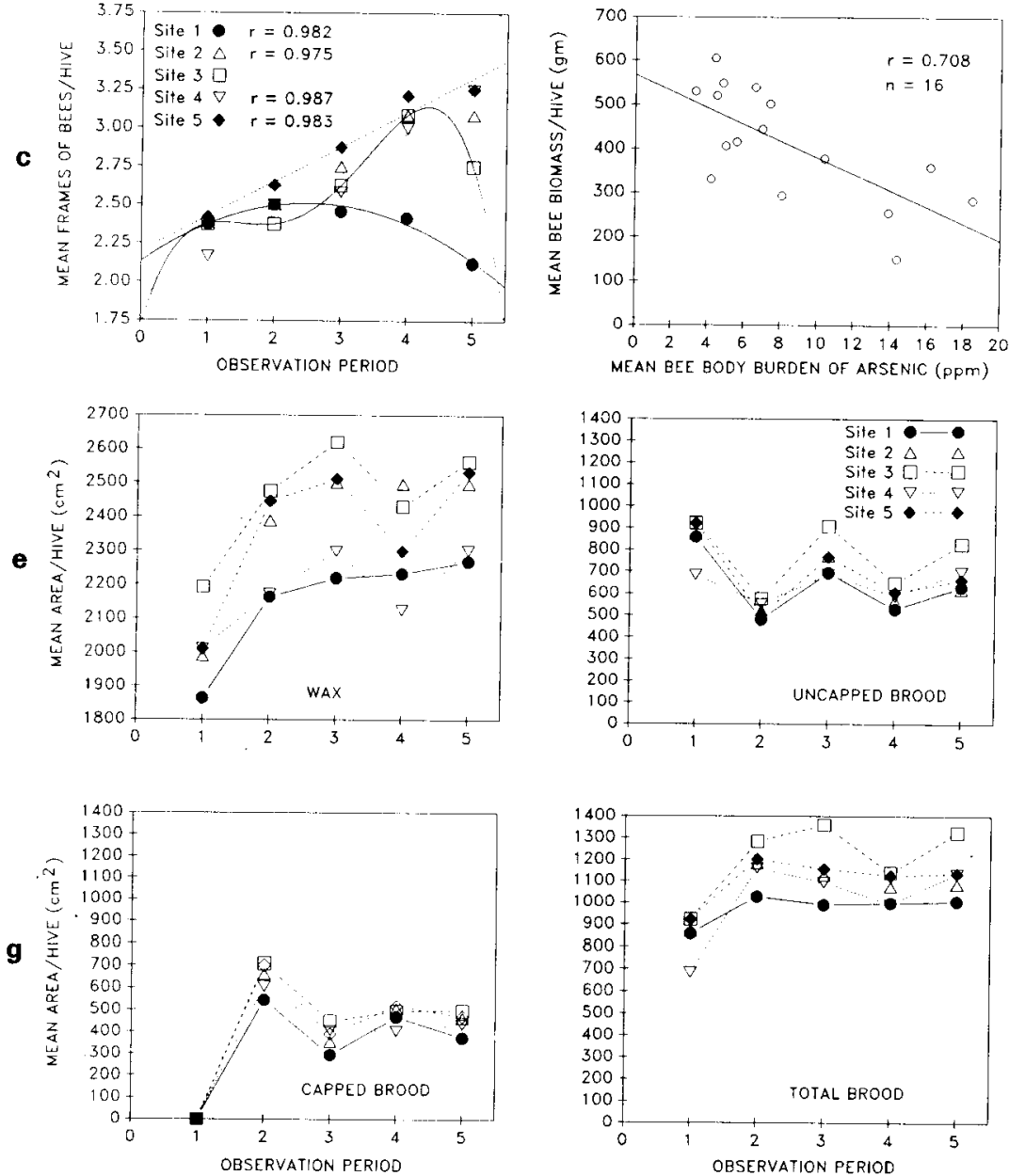

h 
areas per hive of undrawn wax, partially drawn wax, drawn wax, empty cells, nectar, capped honey, pollen, open brood (eggs and larvae), capped brood (pupae), and numbers of drone and queen cells.

To make the tracings, one observer placed the queen from each hive in a screen cage, then shook the bees from the frames. A second observer made the tracings from the frames. This procedure yielded 8 tracing records (identified by frame) of 11 parameters per hive, for 50 hives, at 5 sites, over 5 weekly intervals.

Accuracy and precision of tracings were checked in the field for randomly chosen hives. To assess accuracy, the person tracing would make a second, slower, more "precise" drawing of the same frame. To assess precision, a duplicate, rapid tracing would be immediately made of the same frame.

Areas for each hive parameter were digitized in the laboratory using a Ladd Research Industries, Inc Graphical Digitizer ${ }^{\circledR}$ (Ladd Research Industries, Burlington, VT) coupled to a Monroe $^{\circledR}$ (Monroe Systems for Business, Morris Plains, NJ) 1830 Programmable Printing Calculator. Accuracy and precision of digitizing were determined for each observer and for each digitizing session. At the beginning of each session and for each set of 20 acetates, test patterns consisting of a square and of small, medium, and large circles were digitized. Results were then compared to control charts. Any results exceeding control limits required corrective action: re-calibration and re-digitizing of any acetates digitized since the last "in compliance" measurements.

Estimates of exposure to arsenic and cadmium were obtained from residues in forager bees. From screens blocking hive entrances, $\approx$ 50 returning forager bees per hive were aspirated into polyethylene sample bags and immediately frozen. Sample bee tissues were dried, ground, and digested in nitric acid. Heavy metal analyses employed atomic absorption spectrophotometry supplemented with hydride vapor generation for arsenic determinations (Bromenshenk et al, 1985; see procedures for details).

Digitized data were entered into computer spreadsheets. Statistical analyses of results for tracings and chemical residue concentrations were conducted with an $\mathrm{IBM}^{\Theta^{\circledR}}$-compatible PC using $\mathrm{BIOM}^{\odot}$ (FJ Rohlf, Stony Brook, NY) and SPSS $/ \mathrm{PC}+{ }^{\odot}$ (Chicago, IL). Analysis of variance, regression, and multiple range tests follow Steel and Torrie (1980) and Sokal and Rohlf (1981).

Statistical comparisons emphasize the final observation period because: 1 ), all colonies started with nearly the same number of bees and the same equipment, so there were no statistical differences at the start of the experiment; 2), significant differences by date had to occur since some of the measured components, not present at the beginning of the experiment, only appeared 2 wk later (eg, capped brood was produced, while the amount of uncapped brood correspondingly decreased); 3), more information was available for the initial and last observation periods (eg, total hive weight, weights of bees versus hive components, and chemical residue values); 4), site-specific differences became more pronounced with time (figs, 1,2).

\section{RESULTS}

\section{Colony responses}

The nucs were self-sustaining, despite frequent and invasive handling. At Site 3, a queen flew out of an opened hive during the fourth week. The colony accepted a replacement, with little apparent disruption of activities.

After the experiment's end on August 19 , the mini-colonies were left at the sites for another month. Eighty d after the initial set-up, the nucs were again sampled for chemical residues, then disassembled and examined. Forty-nine of the original 50 colonies were still alive and appeared to be in good condition.

Nucs facilitated quality assurance and control of data. Observers could trace the frames in a nucleus hive in 10-20 min, a task that could have taken more than $1 \mathrm{~h}$ for a standard hive.

Precision estimates based on 40 pairs of duplicate tracings revealed an overall mean difference of $6.1 \mathrm{~cm}^{2}(\mathrm{SD}=8.90$, $n=40$ ) between tracings. These errors 

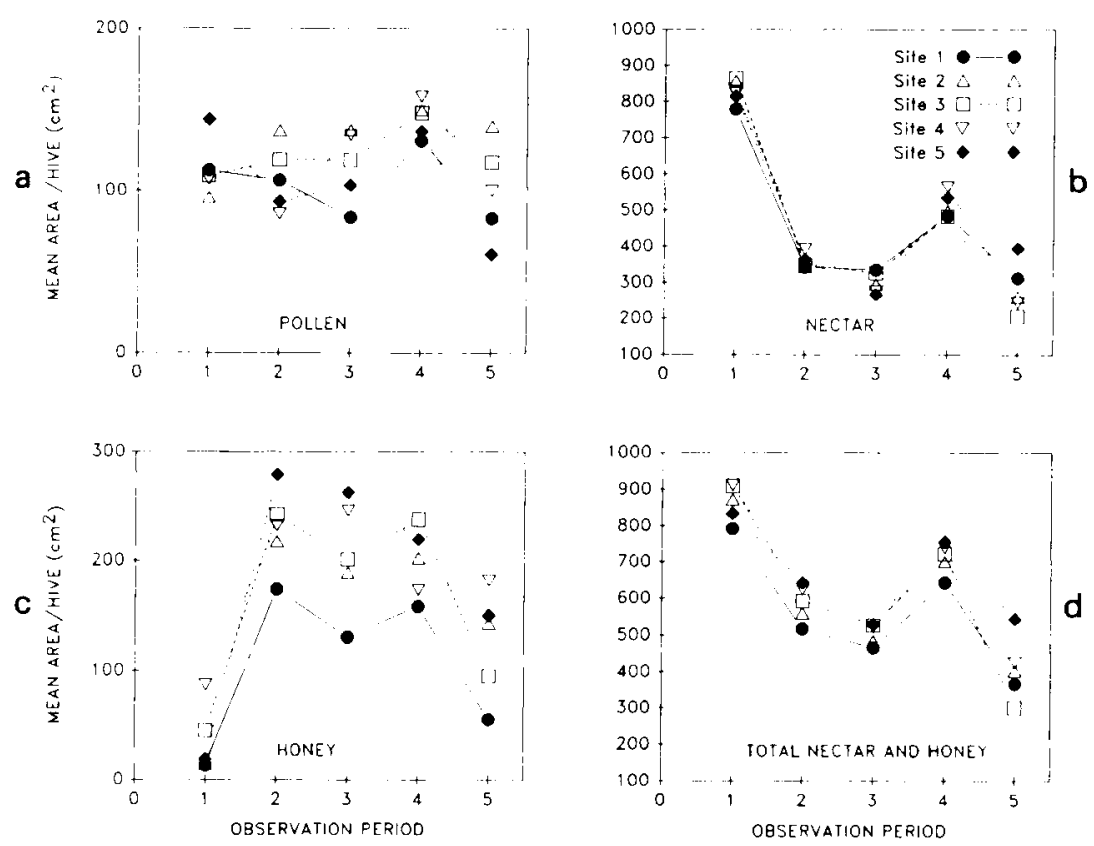

Fig 2.a. Area of pollen stored per hive. Coefficients of variations of $\approx 35 \%$ were observed. $\mathbf{b}$. Nectar stored. Coefficients of variations of $\approx 30 \%$ were observed. c. Area of capped honey. An overall mean $\mathrm{CV}=81.3 \%$ was observed; some CV values exceeded $100 \%$. d. Area of total honey (nectar and capped honey). An overall mean $\mathrm{CV}=\mathbf{2 9 . 2}$ was observed. Confidence intervals were not plotted on the graphs, because they tended to obscure the data points and trends.

were usually small compared to the maximum possible area $\left(\approx 3000 \mathrm{~cm}^{2}\right)$ for each measured aspect. For example, the smallest area was $\approx 60.77 \mathrm{~cm}^{2}(10 \%$ error) for the total mean area of pollen in hives at a site. For most of the components measured, mean areas per hive usually ranged from $300-900 \mathrm{~cm}^{2}$ (< $2 \%$ error).

Accuracy of tracing checks demonstrated a mean difference between rapid and more careful tracings of $11.3 \mathrm{~cm}^{2},(\mathrm{SD}=$ 18.95, $n=44$ ) for all parameters. Based on a sign test, we found no consistent or statistically significant positive or negative bias. The least accurate and precise estimates were obtained when only a few cells existed on a frame, such as sometimes occurred with pollen. Errors were higher for estimates of empty cell areas (which might actually contain eggs) than for areas of capped brood. Scoring cells partially filled with nectar or pollen also contributed to error. However, compared to the overall areas measured for each hive, these errors were relatively small.

Laboratory digitizing contributed relatively few errors. Accuracy, determined by measurements of a $375-\mathrm{cm}^{2}$ test square by several observers, demonstrated a negative bias of $0.3 \%$. However, this value probably equals or exceeds the tolerance for the referenced test square, which was 
drawn on acetate using a metric straightedge. Based on > 200 measurements of several test shapes, precision coefficients of variation (CV) ranged from $0.7-2.0 \%$. The slightly higher CVs were obtained from the smallest digitized areas, ie, those $<18 \mathrm{~cm} 2$.

Mass of bees and of hive parts was determined at the beginning and end of the 40-d experiment. Although each unit began with approximately the same mass of bees, some drifting among colonies occurred. Weekly frame coverage assessments provided an estimate of population size. Measured mass of adult bees was regressed against frames covered by bees (fig 1b). Frame coverage provided a reasonable ( $r=0.962, n=48$ ) estimate of bee mass, which we assume also indicates population size (numbers of bees).

A 1-way analysis of variance of the final mass of bees (arcsine transformed data) at each site yielded an $F$ ratio of 3.87 (4.43 df), significant at $P \leq 0.009$. The arcsine transformation normalized the data and yielded homogeneous variances.

Using Tukey's multiple range test for means, bee mass at Site 1 was statistically different at the $P \leq 0.05$ level from Sites 4 and 5 . Bee mass at Sites 2 and 3 was not statistically different from Sites 1,4 , or 5 .

Food stores as indicated by areas of pollen (fig 2a), nectar (fig 2b) and honey (fig 2c) varied considerably by date. For individual observation periods, differences between sites in the amount of stored pollen, nectar (uncapped cells), and total honey (nectar + capped cells) were not significant $(P \leq 0.05)$. All colonies had stores of pollen and honey or nectar at all observation periods.

Capped honey stores tended to be lowest at Site 1 (fig 2c). A 1-way analysis of variance of the final amount (area) of capped honey by site (logarithmic data transformation) produced an $F$ ratio of 2.39 $(4,43 \mathrm{df})$, "significant" at the $7 \%$ probability level. The logarithmic transformation normalized the data, since standard deviations tended to be proportional to the means.

Capped honey was reduced by $67 \%$ percent at Site 1 compared to Sites 4 and 5 (fig 2c). This change was proportionally greater than the $40 \%$ reduction in the population size of bees (frame coverage and mass) observed at Site 1 (fig 1c). Yet differences in capped honey were only "significant" at the $7 \%$ probability level; whereas differences in bee mass were significant at the $1 \%$ probability level. The most variable hive component measured was within-site values for capped honey; CVs averaged $\approx 69 \%$, but ranged to $>120 \%$ (fig 2c). Total nectar and honey was less variable $(\mathrm{CVs}=$ approximately $27 \%$ ) than capped honey (fig $2 d$ ).

Colonies at Site 1 had fewer adult bees (fig 1c) and less brood (figs $1 \mathrm{f}-\mathrm{h}$ ) than the other sites. Colonies at Site 3 usually produced the most brood (fig $1 f-h$ ), yet had the second-lowest final mass of adult bees (fig 1c). Initially, brood rearing at Site 4 was delayed. The bees were slow to accept one of the 6 queens, and we replaced another queen that the bees rejected. However, the final mass of adult bees at Site 4 was nearly equivalent to Site 5 , which had the largest bee populations (fig 1c).

Wax production (based on comb building) first increased rapidly, then levelled off (fig 1e). Colonies at Site 1 lagged behind in wax production. Fourth-week declines in wax at Sites 3, 4 and 5 were unexpected.

Other hive components such as the amount of undrawn and partially drawn wax, number (area) of empty cells, and number of drone and queen cells provided measurements that were highly variable and difficult or impossible to interpret. 


\section{Exposure to heavy metals}

Arsenic and cadmium concentrations in forager bees revealed a consistent, sitespecific exposure pattern. Shortly after deployment, the sites consistently ranked $1>$ $3>2>4 \geq 5$ from high to low arsenic content of forager bees. Cadmium concentrations ranked $1>3>4>2 \geq 5$. This pattern still remained $40 \mathrm{~d}$ after the experiment ended.

On the 40th day, a 1-way analysis of variance (ANOVA) for heavy metal concentrations (untransformed data) in forager bees at all sites indicated highly significant $(P \leq 0.001)$ differences among locations for mean arsenic and mean cadmium.

A linear curve model, $r=-0.71, n=16$ (fig 1d), represented the best fit for mass of bees versus arsenic content of bees. $N$ equalled 16 , not 48 , because bee samples were pooled from sets of 3 hives at the time of sampling. This limited the number of foragers removed from a hive to 50 bees, minimizing sampling impact.

There was a significant inverse relationship between population size (indicated by bee mass) and arsenic exposure (indicated by arsenic levels in forager bees). Based on the coefficient of determination, different arsenic exposure levels could account for nearly $49 \%$ of the variation in bee population size.

The above conclusion was confirmed by Kendall's coefficient of rank correlation, which tests whether 2 rankings are substantilly in agreement with one another (Sokal and Rholf, 1981). The coefficient of rank correlation was 0.483 , significant at the $1 \%$ level.

Regression analysis of cadmium versus bee mass did not yield statistically significant values. Cadmium levels, like arsenic, were highest at Sites 1 and 3. Unlike arsenic, cadmium concentrations in bee tis- sues were higher at Site 4 than at Sites 2 and 5.

Bees at Site 1 sustained the highest exposures to arsenic and cadmium. Body burdens of arsenic ranged from 10.1-18.5 ppm (dry weight), and cadmium from 2.8$5.5 \mathrm{ppm}$. Bees at Sites 2 and 3 had intermediate arsenic exposures of 5.0-9.4 and 6.1-10.4 ppm, respectively. Cadmium at Site 2 varied from 1.9-2.6 ppm, and Site 3 ranged from 2.3-3.8 ppm. Lowest metal concentrations were $3.3-5.6 \mathrm{ppm}$ for arsenic at Sites 4 and 5, and 1.4-2.1 ppm cadmium at Site 5 . Cadmium varied from 1.85-3.10 ppm at Site 4. At all sites, arsenic and cadmium were elevated above background levels of $0.1-1.0 \mathrm{ppm}$ arsenic and $<0.04 \mathrm{ppm}$ cadmium for colonies not in the exposure area (Bromenshenk et al, 1985).

At Site 1, exposed to the highest concentrations of arsenic and cadmium, adult bee populations increased slightly, then declined throughout the experiment. Populations at Site 3 , which received the second highest exposure to arsenic and cadmium, displayed population increase and decline (fig 1c). Adult bee populations at the sites of lowest exposure to arsenic and cadmium (2, 4 and 5) steadily increased following the emergence of the first brood (fig 1c).

From the emergence of first-brood adults until the experiment's end, population growth curves at the 3 lowest exposure sites $(2,4,5)$ were described by a linear model (fig 1c). Growth of bee populations at the high exposure sites (1 and 3) could not be described by a linear model (fig 1c). A quadratic model was used to describe Site 1 data. Site 3 could not be described by the same model as Site 1. The stepwise growth curve suggested by the Site 3 data may be an artifact of the limited number of observation periods. We used a 4th order polynomial as a bio- 
logically meaningless model for comparison with other sites (no $r$ values shown because of zero degrees of freedom).

\section{DISCUSSION AND CONCLUSION}

The nuc's small size and ease of handling permitted the use of tracings to obtain accurate and precise measures of comb areas. Actual measurements of several aspects of full-size hives usually are impractical, since they are so labor-intensive and time consuming. Visual estimates of hive components can reduce observation time (Jeffree, 1958), but observer bias and subjectivity are difficult to control. This reduces data comparability. Bromenshenk and Lockwood-Ogan (1990) reviewed methods for measuring hive components, including a new method for digitizing hive components in situ.

The depressed adult bee populations observed at Site 1 (the site of highest exposure to arsenic and cadmium) reflected smaller broods and rate of comb building. This site also had the smallest stores of surplus (capped) honey.

Site 3 demonstrated the second-highest exposures to arsenic and cadmium and at the end of the study had the secondlowest mass of bees and honey, although brood rearing was higher than at other sites. Throughout the experiment, Sites 4 and 5 had more bees, and honey, and lower arsenic exposures, than any other site.

Food availability did not appear to be the factor limiting population size at Sites 1 and 3 or at any of the other sites. All colonies had stores of pollen, nectar, and honey at all times. It seems more likely that small adult populations and fewer foragers at Sites 1 and 3 led to reduced hoarding.

Reduced brood rearing apparently contributed somewhat to the adult population decline at Site 1. Increased brood rearing at Site 3 might have been a densitydependent response to fewer adult bees. Pollen from the high exposure sites (1 and 3) contained high concentrations of arsenic and cadmium (Bromenshenk et al, 1985). Since pollen is fed to developing brood, the decreased brood at Site 1 may have resulted from larval ingestion of toxic pollen.

At Site 1, arsenic in bees exceeded lethal levels (see Bromenshenk, 1980 for a review on toxicity). Sites 2 and 3 displayed concentrations considered poisonous or at least hazardous, and potentially lifeshortening. Although elevated when compared to background levels, the amounts of arsenic in bees at Sites 4 and 5 were below those generally associated with arsenic toxicity.

Virtually nothing has been published about cadmium toxicity to bees, although it is toxic to many other organisms. Our ongoing studies indicate that cadmium is approximately as toxic as arsenic (Cronn, unpublished data). Lack of a correlation between cadmium levels in bee tissues and observed colony responses resulted from somewhat higher values of cadmium at Site 4 compared to Site 2 and does not mean that cadmium has no effect on bee colonies.

Based on our previous findings, cadmium is distributed somewhat differently from arsenic around Puget Sound, probably because arsenic was entering the atmosphere every day, whereas emissions nearly $70 \mathrm{yr}$ earlier produced most of the cadmium (Bromenshenk et al, 1985).

Synergistic or additive effects with arsenic may have occurred at Sites 1 and 3. In addition, the amount of cadmium at Site 4 , although considerably elevated above background levels, could have been below the toxicity threshold. 
The loss of wax from combs at 3 of the sites was not anticipated. Bees move wax within a colony to cap honey or to repair comb (Dadant and Sons, 1975). Digitized tracings and our visual observations indicate that bees may break down newly formed wax comb. Whether this wax was metabolized, used for capping, or eliminated is unknown.

Based on all components measured, adult population size, as indicated by the number of frames covered by clustered bees or the mass of bees, was the most sensitive and least variable indicator of colony effects. Frame counts were the easiest test to conduct. Surplus honey may also indicate effects, but large within-site variability reduced our ability to distinguish statistically significant changes in honey yield. Brood rearing, wax production, and food storage (pollen, nectar, and honey) information was useful for final interpretation. It also provided data concerning the total dynamics and energy flow within the colonies.

The results indicate that mini-colonies can be used under field conditions to identify and quantify the effects of exposure to environmental contaminants such as heavy metals. Low costs and manageability permit increased replication, which improves discernment of statistically significant responses.

\section{ACKNOWLEDGMENTS}

We wish to thank the beekeepers of Puget Sound and residents of Vashon Island for their assistance and support. Thanks also are due to the Environmental Protection Agency Project Officers $E$ Preston and $C$ Bishop for their assistance.

Résumé - Dynamique des populations de petites colonies d'abeilles exposées à des polluants d'origine industrielle. Des colonies d'abeilles de taille standard ont déjà été utilisées pour contrôler des polluants chimiques, principalement pour connaître leur répartition à large échelle. Dans cette étude, ce sont de petites colonies, (4 cadres, environ 4500 abeilles) qui ont servi à étudier l'impact de la pollution. Cinquante nucléi ont été répartis en 5 sites le long d'un gradient d'exposition à l'arsenic et au cadmium, sur l'île de Vashon, dans l'état de Washington (fig 1a). Ces colonies ont subvenu elles-mêmes à leurs besoins et ont concurrencé avec succès des colonies standard dans l'exploitation des ressources alimentaires. Au bout de 40 jours, des différences statistiquement significatives sont apparues entre les sites dans la masse et le nombre moyens d'abeilles $(P \leq 0,01$, fig $1 \mathrm{~b})$, dans la production de miel ( $P \leq 0,07$, fig $2 b$ ) et dans les teneurs en arsenic et en cadmium des ouvrières butineuses ( $P \leq 0,001$, fig $1 \mathrm{~d}$ ). Les populations d'abeilles étaient plus faibles d'environ $40 \%$ (fig 1 b) et la production de miel d'environ $67 \%$ (fig $2 b$ ) sur le site le plus pollué à l'arsenic et au cadmium par rapport à celui qui l'était le moins. La taille de la population et les productions de miel étaient corrélées négativement $(P \leq 0,005)$ avec la teneur en arsenic des abeilles. Ces résultats sont discutés en relation avec les changements observés dans d'autres caractéristiques des colonies, telles que le stockage du miel et du nectar, les provisions de pollen, la production de cire, la quantité de couvain operculé et non operculé, le poids de la ruche et le nombre d'abeilles sur les rayons.

Apis mellifera / indicateur biologique / pollution / dynamique des populations

Zusammenfassung - Populationsdynamik von Kleinvölkern bei Einwirkung industrieller Schadstoffe. Bienenvölker von 
Standardgröße wurden zur Erfassung chemischer Schadstoffe benutzt, besonders hinsichtlich deren großräumigen Verteilung. In dieser Untersuchung hingegen wurden Kleinvölker (4-Waben-Ableger mit ca 4500 Bienen) als Alternative zu Vollvölkern benutzt, um den Einfluß chemischer Schadstoffe zu erfassen. Fünfzig Kernvölker wurden auf fünf Standorte entlang eines Expositionsgradienten für Arsen und Cadmium auf Vashon Island, Washington (USA), aufgestellt (Abb 1a). Diese Völker konnten sich selbst erhalten und konkurrierten erfolgreich mit Vollvölkern bei den Trachtpflanzen. Nach 40 Tagen wurden statistisch signifikante Unterschiede zwischen den Standorten für die mittlere Masse und Zahl der Bienen ( $P \leq 0,01$, Abb 1b) beobachtet, Honigertrag $(P \leq 0,07$, $\mathrm{Abb} 2 \mathrm{~b}$ ) und den Arsen- und Cadmiumgehalt der Trachtbienen ( $P \leq 0,001$, Abb 1d). Die Bienenmenge war am Standort mit der höchsten Arsen- und Cadmiumbelastung um etwa $40 \%$ geringer als am Standort mit der geringsten Belastung, die Honigproduktion war sogar um $67 \%$ geringer. Populationsgröße und Honigertrag waren mit dem Arsengehalt der Bienen negativ korreliert $(P \leq 0,005)$. Diese Ergebnisse werden in Zusammenhang mit Veränderungen von anderen Volksmerkmalen diskutiert, wie Stapelung von Honig und Nektar, Pollenvorräte, Wachserzeugung, Menge verdeckelter und unverdeckelter Brut, Volksgewicht und Anzahl der von Bienen bedeckten Waben.

\section{Apis mellifera / Populationsdynamik / Bioindikator / Schadstoff}

\section{REFERENCES}

Anderson JF, Wojtas MA (1986) Honey bees (Hymenoptera: Apidae) contaminated with pesticides and polychlorinated biphenyls. $J$ Econ Entomol 79, 1200-1205

Bromenshenk JJ (1979) Monitoring environmental materials and specimen banking using terrestrial insects with particular reference to inorganic substances and pesticides. In: Monitoring Environmental Materials and Specimen Banking (Leupke NP, ed) Martinus Nijhoff, The Hague

Bromenshenk JJ (1980) Accumulation and transfer of fluoride and other trace elements in honey bees near the Colstrip Power Plants. In: The Bioenvironmental Impact of a Coal-Fired Power Plant, Fifth Interim Report. US Environmental Protection Agency, Corvallis Environ Res Lab, EPA-600/3-80-052, 72-95

Bromenshenk JJ (1988) Regional monitoring of pollutants with honey bees. In: Progress in Environmental Specimen Banking: NBS Spec Publ 740. National Bureau of Standards, Washington, DC, 156-170

Bromenshenk JJ, Preston EM (1986) Public participation in environmental monitoring: a means of attaining network capability. Environ Monit Assess 6, 35-47

Bromenshenk JJ, Lockwood-Ogan N (1990) The sonic digitizer as an alternative method to assess honey bee (Hymenoptera: Apidae) colony dynamics. J Econ Entomol 83 (5), 1791-1794

Bromenshenk JJ, Carlson SR, Simpson JC, Thomas JM (1985) Pollution monitoring of Puget Sound with honey bees. Science 227, 632-634

Celli G (1983) L'apa come insetto test della salute di un territorio. Apic Mod 75, 133-140

Dadant and Sons (eds) (1975) The Hive and the Honey Bee. Journal Printing Co, Carthage, IL, revised edn

Fritzsch W, Bremer R (1975) Bienengesundheitsdienst. Jena (Cited in Hoffel and Muller, 1983)

Höffel I, Müller P (1983) Schwermetalliückstände in Honigbienen (Apis mellifica $L$ ) in einem Ökosystem (Saarbrücken). Forum StädteHygiene 34, 191-193 
Jeffree EP (1958) A shaped wire grid for estimating quantities of brood and pollen in combs. Bee World 39, 115-118

Morse RA, Culliney TW, Gutenmann WH, Littman CB, Lisk DJ (1987) Polychorinated biphenyls in honey bees. Bull Environ Contam Toxicol 38, 271-276

Sokal RR, Rohlf FJ (1981) Biometry: The Principles and Practice of Statistics in Biological
Research. WH Freeman and Co, San Francisco, CA, 2nd edn

Steel RGD, Torrie JH (1980) Principles and Procedures of Statistics: A Biometrical Approach. McGraw-Hill Book Co, New York

Wallwork-Barber MK, Ferenbaugh RW, Gladney ES (1982) The use of honey bees as monitors of environmental pollution. Am Bee J $122,770-772$ 